\title{
Elaboration and characterization of Japanese Raisin Tree (Hovenia dulcis Thumb.) pseudofruits fermented alcoholic beverage
}

\author{
Juliana Tensol PINTO ${ }^{1 *}$, Luana Farah ALVARENGA², Diego Pinto de OLIVEIRA², Tânia Toledo de OLIVEIRA ${ }^{1}$, \\ Rosane Freitas SCHWAN ${ }^{3}$, Disney Ribeiro DIAS ${ }^{3}$, José Humberto de QUEIROZ ${ }^{1}$
}

\begin{abstract}
Hovenia dulcis pseudofruits have underexplored properties for food purposes, despite their pleasant sensory characteristics and therapeutic benefits. The aim of this study was the elaboration and chemical characterization of the alcoholic fermented beverage of $\mathrm{H}$. dulcis, using selected strain of Saccharomyces cerevisiae (CCMA 0200). The resulting fermented beverage presented high content of phenolic compounds and antioxidant activity when compared to other fruits and beverages (DPPH and ABTS assay). The alcohol content was $12.9^{\circ} \mathrm{GL}$ and total sugars $3.57 \mathrm{~g} / \mathrm{L}$. By the GC-MS analysis, 39 compounds were identified including metabolites with therapeutic potential such as eugenol, trans-farnesol salicylates. The flavonoid dihidromyricetin was identified and quantified $(75.17 \mathrm{mg} / \mathrm{L})$ by HPLC-DAD and UPLC-MS/MS. The results reinforce the interest on nutraceutical and functional properties of this beverage and opens perspectives for new studies that value this underexplored pseudofruit.
\end{abstract}

Keywords: Hovenia dulcis; fermented beverage; volatile compounds; antioxidant; dyhidromyricetin.

Practical Application: The preparation of an alcoholic fermented from pseudofruits of Hovenia dulcis is unprecedented and results in a technological use strategy, trough simple and reproducible methodology, which may value this raw material. H. dulcis species is widely used as food products in Eastern countries, but in Western countries is still unexplored.

\section{Introduction}

Hovenia dulcis (Thunberg) is a native species from eastern Asia and was introduced in Brazil, probably in 1987, by the Brazilian Company of Agricultural Research (CNPFlorestas/EMBRAPA) for ornamental and reforestation purposes. H. dulcis reproduces by seeds and has consistent fruiting, which explains the large capacity of dispersion, besides it is a very rustic and fast growth species In addition, the fruits with pleasant taste are consumed by people and animals, which is a further contribution to seed dispersal of the species (Carvalho, 1994). In China, Japan and Korea, the $H$. dulcis extracts are processed as tablets, powders, liquids or granules and used as dietary supplements (Hyun et al., 2010). Other food products using $H$. dulcis pseudofruits have been described as vinegar (Xiang et al., 2012), non-alcoholic beverage containing extract of $H$. dulcis pseudofruits (Park et al., 2006) and fruit soy sauce (Jung et al., 2012). However, despite its wide application and knowledge of therapeutic benefits in Asia for more than a millennium, Hovenia dulcis is not commonly used for medicinal purposes in Western countries (Hyun et al., 2010).

Despite their pleasant sensory characteristics, the $H$. dulcis fruits, have unexplored properties for food purposes (Bampi et al., 2010). Due to the ability of some plants have to adapt to different climates, there is an interest in exploring their culture and their application, since they require no significant handling and can be cultivated for productive purposes (Carvalho, 1994).
Considering the high sugar content in the H. dulcis pseudofruits, $16.28 \%$ according Bampi et al. (2010), this species presented as a good alternative for the development of alcoholic beverage. Combined with the high sugar content and pleasant sensory characteristics of $\mathrm{H}$. dulcis, the therapeutic benefits already described can add functional potential to the fermented beverage.

The aim of this study was to elaborate a fermented alcoholic beverage of $H$. dulcis pseudofruits. Antioxidant activity and chemical characterization of the beverage were performed.

\section{Materials and methods}

\subsection{Alcoholic fermentation}

The $H$. dulcis fruits were manually collected at the Federal University of Lavras, Lavras, Minas Gerais, those without physical injury, rot or gross contamination were selected and subsequently washed in $5 \mathrm{ppm}$ chlorinated water and rinsed under running water. The whole juice was obtained by grinding the intact and washed fruits in a multiprocessor. The juice was modified with sucrose solution to reach a value of $20^{\circ}$ Brix, being added potassium metabisulphite $100 \mathrm{mg} \mathrm{SO}_{2} /$ liter for bacterial control. The juice was inoculated with approximately $10^{7} \mathrm{cells} / \mathrm{mL}$ of the selected yeast Saccharomyces cerevisiae (CCMA 0200), strain that showed good results in previous studies involving fermentation 
(Duarte et al., 2010; Oliveira et al., 2011; Souza et al., 2011), and is commercially available (LNF CA $11^{\circ}$ ). The fermentation occurred in Erlenmeyer flasks in a total volume of 1L, in duplicate at $26^{\circ} \mathrm{C}$ (BOD incubator) for 156 hours. The parameters: ${ }^{\circ}$ Brix (refractometer), number of viable cells (counting in a Neubauer chamber) and $\mathrm{pH}$ (digital potentiometer) were evaluated at each 12 hours, until the end of fermentation (stabilization of ${ }^{\circ}$ Brix). Subsequently, the beverages were filtered under vacuum Kitassato coupled to a Büchner funnel using cellulose filter and pasteurized at $65^{\circ} \mathrm{C}$ for 30 minutes in a thermostatic bath.

\subsection{Chromatographic analysis}

Characterization and quantification of alcohols, carbohydrates and organic acids

Alcohols, carbohydrates and organic acids were quantified by high-performance liquid chromatography (HPLC) using adapted methodology of Schwan et al. (2001), in Shimadzu LC-10Ai chromatograph, SCR-101H Shimpack column (Shimadzu). Carbohydrates and alcohols were detected by refractive index (RID-10A detector) at $30^{\circ} \mathrm{C}$ and the organic acids by the ultraviolet detector (SPD-10Ai) at $210 \mathrm{~nm}$ at $50^{\circ} \mathrm{C}$, both using the perchloric acid mobile phase at $100 \mathrm{mM}, 0.6 \mathrm{~mL} \mathrm{~min}^{-1}$ flow. The quantitation was performed from the interpolation of areas in calibration curves, using certified standard.

\section{Characterization and quantification of vanilic acid and dihydromyricetin by HPLC-DAD}

The identification and quantification of vanilic acid and dihydromyricetin was based on adapted methodology from Garcia et al. (2016). Analysis were carried out on a Waters alliance 2695 HPLC system composed of quaternary pump, an auto sampler, a photodiode array detector (DAD) 2996 and a Waters Empower pro data handling system (Waters Corporation, Milford, USA). The analysis was performed on a LiChrospher 100 RP-18 column (250 mm×4 mm i.d.,5_m; Merck, Darmstadt, Germany), in combination with a LiChrospher 100 RP-18 guard column ( $4 \mathrm{~mm} \times 4 \mathrm{~mm}$ i.d., 5_m; Merck, Darmstadt, Germany). The HPLC profiles were recorded employing a linear gradient of $\mathrm{H}_{2} \mathrm{O}(\mathrm{A})$ and $\mathrm{CH}_{3} \mathrm{CN}(\mathrm{B})$, each one containing $0.01 \%$ phosphoric acid (v/v), as follows: 0 min $95 \%$ A, $5 \%$ B; 35 min $70 \%$ A, 30\% B; 40 min 5\%A, 95\% B; 43 min 5\%A, 95\% B; 45 min 95\%A, $5 \% \mathrm{~B}$, at a temperature of $40{ }^{\circ} \mathrm{C}$ and flow rate of $0.70 \mathrm{ml} / \mathrm{min}$. The chromatograms were obtained at $280 \mathrm{~nm}$ and UV spectra from 195 to $400 \mathrm{~nm}$ were recorded on line. The reference compounds were dissolved in methanol (HPLC-grade) to concentrations of $0.5 \mathrm{mg} / \mathrm{ml}$. After centrifugation at $8400 \mathrm{~g}$, the sample solutions $(10 \mu \mathrm{L})$ and the fruit wine were injected into the apparatus in triplicate. Peaks identification in the chromatograms of the wine was achieved by comparison of their retention times for reference compounds in the same conditions. Co-injection of the of the fruit wine with reference compounds and comparison with uv spectra was also employed for peak identification in the fruit wine. The quantities of the compounds were expressed in miligrams per liter $(\mathrm{mg} / \mathrm{L})$ by correlating the area of the compound with the calibration curve of standards built in concentrations of $0.5-50 \mathrm{mg} / \mathrm{mL}$.

\section{Characterization of volatile compounds}

The alcoholic fermented compounds were measured in gas chromatography coupled to a mass spectrometer (GC-MS), Shimadzu GC model QP2010 equipped with a mass spectrometry (MS) and a capillary column of silica DB-Wax $(30 . \mathrm{m} / 0.25 \mathrm{~mm} / 0.25 \mu \mathrm{m})$. The volatile compounds were extracted by the SPME fiber exposition into the headspace for $30 \mathrm{~min}$ at $60^{\circ} \mathrm{C}$. The temperature program began with $5 \mathrm{~min}$ at $60^{\circ} \mathrm{C}$, followed by a gradient of $60^{\circ} \mathrm{C}$ to $230^{\circ} \mathrm{C}$ at $10^{\circ} \mathrm{C} / \mathrm{min}$; the temperature was then maintained at $230^{\circ} \mathrm{C}$ for $15 \mathrm{~min}$. The injector and detector temperatures were maintained at $230^{\circ} \mathrm{C}$. The carrier gas $(\mathrm{He})$ was used at a flow rate of $1.2 \mathrm{~mL} / \mathrm{min}$. Injections were performed by fiber exposition for $2 \mathrm{~min}$. Volatile compounds were identified by comparing the mass spectra and retention time, based on adapted methodology from Rodriguez-Campos et al. (2011).

\section{Characterization of dihydromyricetin by UPLC-MS/MS}

The characterization of dihydromyricetin was based on adapted methodology from Henriques et al. (2016). UPLC-MS/MS analysis were carried out using an Acquity Ultra Performance LC system (Waters, Milford, MA, USA) coupled simultaneously to both PDA 2996 photo diode array detector (Waters, Milford, MA, USA) and an Acquity TQ Detector (Waters MS Technologies, Manchester, UK), equipped with a Z-spray electrospray ionization (ESI) source operating in positive and negative mode. MassLynx software (version 4.1, Waters, Milford, MA, USA) was used to control the instruments, as well as for data acquisition and processing.

\subsection{Determination of antioxidant activity}

The total phenolic content and antioxidant activity by DPPH and ABTS methods were determined in H. dulcis pulp, fermented alcoholic and commercial white wine for comparison. The concentration of phenolic compounds was determined according to described by Waterhouse (2005), using calibration curve of gallic acid and results were expressed as gallic acid equivalents (GAE)/100 g.

The antioxidant capacity was determined by the modified DPPH method (Brand-Williams et al., 1995). A methanol solution containing $0.06 \mathrm{mM}$ DPPH was prepared. After adjusting the blank with methanol, an aliquot of $100 \mu \mathrm{l}$ of fruit extract was added to $3.9 \mathrm{~mL}$ of this solution. The decrease in absorbance at $515 \mathrm{~nm}$ was measured at $1 \mathrm{~min}$ intervals for the first $10 \mathrm{~min}$, and then at 5 min intervals until stabilization.

The ABTS.+ assay was based on a method developed by Miller et al. (1993) with modifications. ABTS ${ }^{+}$radical cations were produced by reacting $7 \mathrm{mM}$ ABTS stock solution with $145 \mathrm{mM}$ potassium persulfate and allowing the mixture to stand in the dark for $12 \mathrm{~h}$ before use. Then, the solution was diluted with ethanol to reach an absorbance of $0.70 \pm 0.02$ at room temperature at $734 \mathrm{~nm}$. Samples $(30 \mu \mathrm{l})$ or trolox standard were added to $3 \mathrm{ml}$ of diluted ABTS. ${ }^{+}$solution, the absorbance were recorded at 6 min after mixing. Known trolox concentrations were used to build a calibration curve and the results were expressed as $\mu \mathrm{M}$ trolox/g fruit. 


\section{Results and discussion}

\subsection{Alcoholic fermentation}

After the inoculation with the Saccharomyces cerevisae (CCMA 0200) strain, the ${ }^{\circ}$ Brix decreased gradually until the stabilization at $5^{\circ}$ Brix after 156 hours of fermentation. The $\mathrm{pH}$ observed in the final fermented was 5.1. The number of viable cells remained between $10^{7}$ and $10^{8}$ cells $\mathrm{mL}^{-1}$, similar to the behavior observed by Oliveira et al. (2011) and Souza et al. (2011), using the same strain (CCMA 0200) for cagaita and apple fermentation, respectively. Whereas $H$. dulcis fermented is a unique beverage, there are no parameters to compare the fermentation kinetics and final characteristic of the product.

\subsection{Chromatography analysis}

The chromatography analysis by HPLC-DAD allowed the identification of different organic acids, sugars and alcohols and dihidromyricetin (Table 1). The alcohol content of the beverage $\left(101.84 \mathrm{~g} / \mathrm{L}\right.$ or $\left.12.9^{\circ} \mathrm{GL}\right)$ was similar to the content observed for the cajá, $12^{\circ} \mathrm{GL}$ (Dias et al., 2003) and caju, $11.5^{\circ} \mathrm{GL}$ fermented beverages (Torres et al., 2006). The glycerol content was similar to the content observed by Duarte et al. (2010) $\left(5.35 \mathrm{~g} \mathrm{~L}^{-1}\right)$ during the process to obtain gabiroba fermented beverage, and lower than the values observed for jabuticaba and umbu fermented beverages $(7.56 \mathrm{~g} / \mathrm{L}$ and $7.69 \mathrm{~g} / \mathrm{L})$, using the same yeast (CCMA 0200).

The fructose content was similar to the content observed by Childs et al. (2015), between $1.9 \mathrm{~g} \mathrm{~L}^{-1}$ and $2.7 \mathrm{~g} \mathrm{~L}^{-1}$ for different modified grape musts. The sugar content $\left(3.57 \mathrm{~g} \mathrm{~L}^{-1}\right)$ was lower than $5.0 \mathrm{~g} \mathrm{~L}^{-1}$, which classifies the beverage as "dry". Regarding the organic acid content, only one study was found using $\mathrm{H}$. dulcis pseudofruits for vinegar production (Xiang et al., 2012). In this study, the authors described that the alcoholic fermented beverage used as substrate for the acetic fermentation presented lower content of acetic, succinic and malic acids $(295.09 \mathrm{mg} / \mathrm{L}$; $71.52 \mathrm{mg} / \mathrm{L}$ and $41.91 \mathrm{mg} / \mathrm{L}$, respectively) and higher tartaric and lactic acid content $(2057.85 \mathrm{mg} / \mathrm{L}$ and $764.42 \mathrm{mg} / \mathrm{L}$ respectively) than the present study. According to the same authors, the lack of data and the regional variables interference make difficult the metabolites content comparison.

The vanilic acid and dihidromyricetin was identified together once that the developed method allowed the separation with good resolution, the Figure 1 shows the chromatograms of the fruit wine, isolated chemical compounds and co-injection with the both. The peaks of the vanilic acid and dihydromyricetin in the fruit wine showed same retention time and uv spectra that standard compounds, was observed the increased of the peaks of the compounds in the chromatogram of the co-injection analysis (Figure 1C). The presence of vanillic acid is typical in wines (Xiao et al., 2015) and a constituent of vanilla flavor (Rao \& Ravishankar, 2000). The vanillic acid has also been described in H. dulcis pseudofruits (Li et al., 2005).

The dihydromyricetin (DHM) is a very common flavonone in H. dulcis (Park et al., 2016; Yoo et al., 2006). This compound presence is extremely important to establish a quality parameter, once it's a new beverage. Furthermore, recent studies demonstrate the potential of DHM in disorders related to liver and alcohol detoxification, functional evidence that can add therapeutic value to fermented due the possibility that substance ameliorate the effects caused by alcohol (Shen et al., 2012). The identification and quantification represent quality parameters that allow the adulteration control the raw material for fermentation and nutraceutical enrichment, in this propose, the presence of this compound was confirmed by UPLC-MS/MS analysis, the Table 2 shows the main fragments and the Figure 2 shows the fragmentation proposes for the main peaks.

The MS/MS analysis of the DHM (Figure 2) showed classic fragmentation of flavanones (Tsimogiannis et al., 2007), like the lost of the ring B (a) fragment and the cynamoil (c) fragment, comom in B ring, but the bolth shoed same mass in positive and negative mode. It's possible observe the fragment of A ring in positive mode with mass of 153.04 .

Shen et al. (2012) demonstrates that DHM potently $(1 \mathrm{mg} / \mathrm{Kg})$ counteracts acute EtOH intoxication. DHM antagonizes EtOH exposure/removal-induced alterations in responsiveness of $\mathrm{GABA}_{\mathrm{A}}$ Rs and ameliorates EtOH exposure/withdrawal-induced behavioral changes, including tolerance to $\mathrm{EtOH}$, increase in basal anxiety. At the same doses, DHM does not cause intoxication, sedation, anesthesia, nor hyperexcitability, and prevents the escalation of alcohol consumption in an intermittent voluntary alcohol intake paradigm in rats.

Others studies demonstrated that DHM effectively inhibits proliferation and induces apoptosis in hepatocellular carcinoma (HepG2). In addition, DHM exhibited no significant hepatotoxicity

Table 1. Organic acids, sugars and alcohol contents detected in the fermented alcoholic beverage of Hovenia dulcis by HPLC analysis.

\begin{tabular}{ccc}
\hline Organic acids & Concentration $(\mathbf{m g} / \mathbf{L})$ & Sugars \\
\hline Tartaric & $469.46 \pm 13.87$ & Concentration $(\mathbf{g} / \mathrm{L})$ \\
Malic & $138.74 \pm 27.66$ & Sucrose \\
Succinic & $549.18 \pm 25.59$ & Glucose \\
Latic & $483.88 \pm 145.13$ & Fructose \\
Acetic & $994.50 \pm 28.76$ & $0.23 \pm 0.01$ \\
Propionic & $107.23 \pm 15.51$ & \\
Isovaleric & $37.89 \pm 2.53$ & Alcohols \\
Vanillic & $112.59 \pm 2.54$ & Glycerol \\
Others & Concentration (mg/L) & Ethanol
\end{tabular}



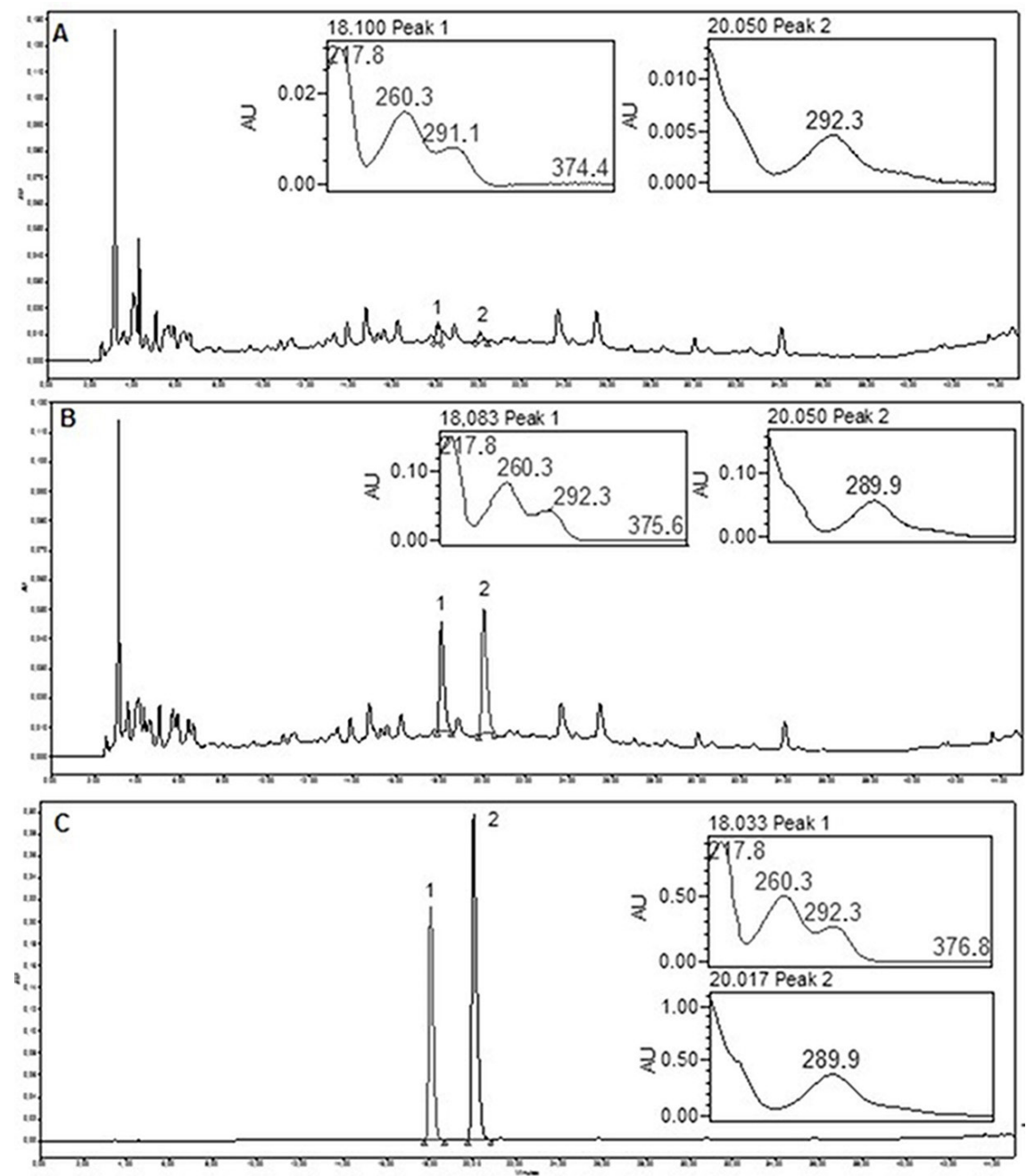

Figure 1. HPLC-DAD characterization of the chemical markers. (A) fruit wine chromatogram; (B) co-injection (fruit wine and compounds) chromatogram; (C) Isolated compounds chromatograms, 1: Vanilic acid; 2: Dihydromyricetin.

Table 2. UPLC MS/MS characterization of dihydromyricetin.

\begin{tabular}{cccc}
\hline Compound & Retention time & {$[\mathrm{M}+\mathrm{H}][\mathrm{M}-\mathrm{H}]$} & MS/MS fragments \\
\hline Dihydromyricetin & 2.7 & 321.26 & $302.52 ; 195.16 ; 153.04 ;$ \\
& & 319.21 & 193.14 \\
\hline
\end{tabular}

to normal liver cells, which supports the possibility of DHM serving as a therapeutic antitumoral candidate (Zhang et al., 2014). Hou et al. (2015) indicates that DHM can protect endothelial cells from oxidative stress, increase production of NO, inhibit production of ROS, and enhance cellular antioxidant defense capabilities, therefore protecting endothelial cells from damaging effects of oxidative stress damage by regulating mitochondrial pathways. Other study indicates that DHM improves glucose and lipid metabolism and exerts anti-inflammatory effects in fatty liver disease (Chen et al., 2015). The amount of recent discoveries about the therapeutic potential of DHM stimulates further studies on natural products containing this substance.

Thirty-nine volatile compounds were identified by GC-MS and are shown in Table 3.
These compounds are typically observed in fruit fermented beverages such as Cupuaçu, Gabiroba, Jaboticaba and Umbu and during cocoa fermentation, as described by Duarte et al. (2010) and Rodriguez-Campos et al. (2011), respectively. Volatile compounds in wine matrices, such as higher alcohols, acids, esters and volatile phenols are not perceived separately (Escudero et al., 2004), being that the totality of the compounds characterizing the flavor of the beverage. The presence of geraniol has also been described in $H$. dulcis pseudofruits and was associated to the typical floral fragrance of this species (Yoshikawa et al., 1993).

Furthermore, molecules with reports of therapeutical effects were detected, such as eugenol, a well-known antioxidant and anti-inflammatory. Recently, Prasad et al. (2016) demonstrated the neurorestorative potential of eugenol in terms of its ability 


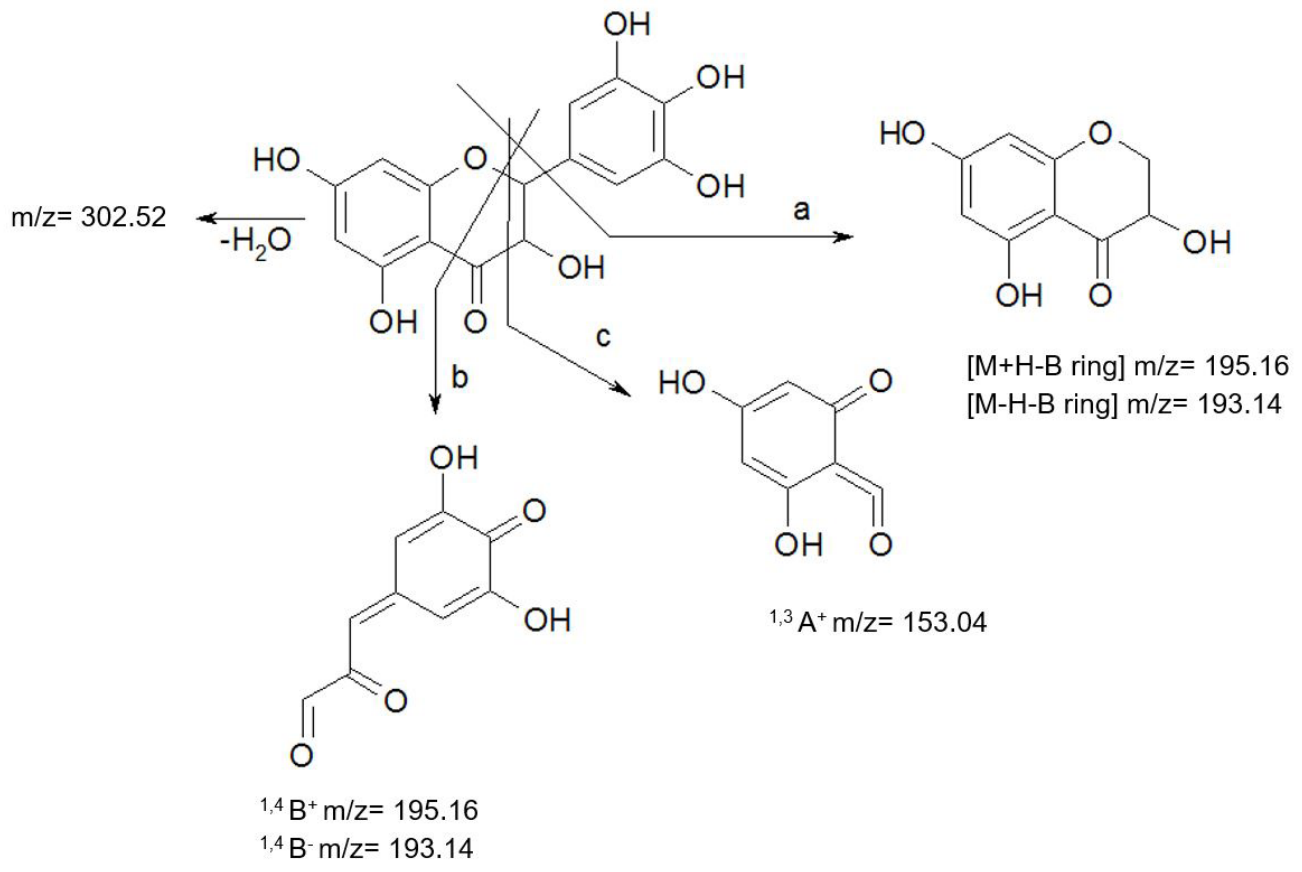

Figure 2. Fragmentation propouses for dihidromyricetin by MS/MS.

to abrogate pre-existing oxidative impairments, mitochondrial dysfunctions and cholinergic deficit in different brain regions. Eugenol shows protective action against the oxidative stress induced by ethanol, evidenced by plasma reduction of transaminases ALT and $\gamma \mathrm{GT}$, and elevate levels of enzymatic antioxidants in rats (Anbu \& Anuradha, 2012).

In addition, sesquiterpenoid trans-farnesol was also detected, this compounds one of the most efficient molecules with hepatoprotective action, according to the in vitro model (3D-QSAR) for hepatoprotective analysis (Vinholes et al., 2014). Santhanasabapathy \& Sudhandiran (2015) shows that farnesol exerts neuroprotective effect by regulating intrinsic apoptotic cascade through its antioxidant effect during LPS-induced neurodegeneration. Beyond that, farnesol ameliorates massive inflammation, oxidative stress and lung injury induced by pneumotoxicants (Qamar \& Sultana, 2008).

Furthermore, it is believed that the presence of salicylates in the diet (fruits and vegetables) may be beneficial due to its effect on inflammatory process, which explains why either salicylic acid as diets with fruits and vegetables assist in prevention of cancer and possibly in other inflammatory diseases (Patterson \& Lawrence, 2001).

\subsection{Antioxidant activity}

According to the results presented on Table 4, $319.9 \pm 15.9 \mathrm{mg}$ EAG $100 \mathrm{~g}^{-1}$ of phenolic compounds was observed on $H$. dulcis pulp. This result was above the observed by Kuskoski et al. (2006) for nine different commercial fruit pulp, with values from 20.0 to $229.6 \mathrm{mg}$ EAG $100 \mathrm{~g}^{-1}$. Breksa et al. (2010) evaluated the phenolic content of 16 grape cultivars
(Vittis vinifera L.) and observed contents between 316.3 and $1141.3 \mathrm{mg}^{\mathrm{E} A G} 100 \mathrm{~g}^{-1}$.

About the fermented alcoholic beverages, the observed results are in accordance to Lins \& Sartori (2014) that studied nine commercial red wines from Brazil and observed phenolic content between 1014.5 and $2971.0 \mathrm{mg}$ EAG. $\mathrm{L}^{-1}$. The fermented alcoholic beverage produced from $H$. dulcis, although it is not classified as a wine (white or red) by the Brazilian Ministry of Agriculture, showed high phenolic content $(2520.3 \pm 17.31 \mathrm{mg}$ EAG. $\mathrm{L}^{-1}$ ). It was almost two times higher than the phenolic content observed for commercial white wine, encouraging the continuation of studies with this fruit. Regarding the antioxidant activity assay, by DPPH method, the $H$. dulcis pulp showed the $\mathrm{EC}_{50}$ of $348.0 \mathrm{~g}$ fruit/g DPPH, similar to those values found for brazilian fruits Cajá, Caju, Umbu and Jambolao and lower than values observed for Acerola, Jabuticaba, Camu-camu and Juçara using the same methodology (Rufino et al., 2010). In addition, the antioxidant activity evaluated by ABTS method also showed higher value (429.55 $\pm 18.10 \mu \mathrm{M}$ Trolox/g fruit) for $H$. dulcis pulp than those observed for 15 of the 18 fruits (around 16.4 to 953.0 $\mu \mathrm{M}$ Trolox/g fruit) studied by Rufino et al. (2010), being lower only when compared to Acerola, Camucamu and Juçara. In regards of alcoholic beverages, Stratil et al. (2008) observed values between 4.30 and 8.44 mmolTrolox $\mathrm{L}^{-1}$ for white wines and Gris et al. (2011) observed values between 11.2 to 23.17 mmolTrolox $\mathrm{L}^{-1}$ for Brazilian red wines. The alcoholic beverage produced from $H$. dulcis showed an antioxidant activity of $11.87 \pm 2.14 \mathrm{mmolTrolox} / \mathrm{L}$ evaluated by ABTS methods, almost three times higher $(4.94 \pm 0.56 \mathrm{mmolTrolox} / \mathrm{L})$ than a commercial white wine. 
Table 3. Volatile compounds identified from $H$. dulcis alcoholic beverage by CG-MS.

\begin{tabular}{|c|c|c|c|}
\hline Group & Compound & Odor descriptors ${ }^{\star}$ & LRI $^{\star *}$ \\
\hline \multirow{3}{*}{ Ketones } & 3-penten-2-one & - & 1106 \\
\hline & 2-heptanone & Acetone, floral, geranium odor & 1225 \\
\hline & Geranyl acetone & Fresh floral & 1834 \\
\hline \multirow{13}{*}{$\begin{array}{l}\text { Higher } \\
\text { Alcohols }\end{array}$} & 2-methyl-1-propanol & Wine & 1098 \\
\hline & 1-butanol & Malty, solvent-like, spirituous & 1140 \\
\hline & 2-methyl-1-butanol & Malty, solvent-like & 1294 \\
\hline & 2-heptanol & Coconut & 1334 \\
\hline & 1-hexanol & Light branches, leaf, fruity & 1337 \\
\hline & 3-hexen-1-ol & Lettuce-like; Strong fruity, green grass & 1374 \\
\hline & 2-octanol & Unpleasantaromaticplant odor & 1385 \\
\hline & 2-propyl-1-pentanol & - & 1395 \\
\hline & 3-ethyl-4-methyl-1-pentanol & - & 1401 \\
\hline & Phenylethylalcohol & Honey, spice, rose, lilac, flowery, caramel & 1912 \\
\hline & 1,4-butanediol & - & 1916 \\
\hline & 2,3-butanediol & Buttery, creammy & 1539 \\
\hline & Docecylalcohol & - & 1973 \\
\hline \multirow{11}{*}{ Acids } & Isobutyricacid & Rancid, butter, cheese, hammy & 1415 \\
\hline & Isovalericacid & Sweat, acid, rancid & 1665 \\
\hline & Hexanoicacid & Sweat, pungent, sickening, rancid, sour & 1832 \\
\hline & 2-hexenoic acid & - & 1971 \\
\hline & Octanoicacid & Sweat, cheese, oily, fatty & 2050 \\
\hline & Nonanoicacid & Green, fat & 2169 \\
\hline & Decanoicacid & Wax, tallow,rancid,soap & 2260 \\
\hline & Benzoicacid & - & 2411 \\
\hline & Dodecanoicacid & Mild, fatty, coconut & 2488 \\
\hline & Tetradecanoicacid & Waxy, fatty, soapy, coconut & 2697 \\
\hline & Hexadecanoicacid & Waxy, creamy, fatty & 2879 \\
\hline \multirow{6}{*}{ Esters } & Isoamylacetate & Banana & 1101 \\
\hline & Ethyldecanoate & Fruity odor & 1633 \\
\hline & Ethylbenzoato & Fruity & 1639 \\
\hline & Methylsalicylate & - & 1765 \\
\hline & Ethylsalicylate & - & 1780 \\
\hline & Isopropylpalmitate & - & 2203 \\
\hline \multirow{6}{*}{ Others } & alpha-Terpineol & Pine, terpenoids & 1687 \\
\hline & cis-Geraniol & Rose-like, citrus-like & 1836 \\
\hline & beta-Citronellol & Citronella & 1757 \\
\hline & Eugenol & Sweet, spicy, clove like, woody & 2133 \\
\hline & trans-Farnesol & mild, delicate, sweet-oily odor & 2315 \\
\hline & Benzothiazole & - & 1959 \\
\hline
\end{tabular}

${ }^{*}$ Feng et al. (2015), Vararu et al. (2016), Bonvehí (2005); ${ }^{*}$ LRI: Linear retention index.

Table 4. Phenolic compounds and antioxidant activity of $H$. dulcis alcoholic fermented and pseudofruits.

\begin{tabular}{|c|c|c|c|}
\hline Sample & Total Phenolic coumponds & $\begin{array}{l}\text { Antioxidant activity } \\
\text { (DPPH method) }\end{array}$ & $\begin{array}{l}\text { Antioxidant activity } \\
\text { (ABTS method) }\end{array}$ \\
\hline H. dulcis alcoholic fermented & $2520.3 \pm 17.31\left(\mathrm{mg}\right.$ EAG. $\left.\mathrm{L}^{-1}\right)$ & $\% \mathrm{AAT}^{*}=80.22 \pm 1.77$ & $11.87 \pm 2.14 \mathrm{mmolTrolox} / \mathrm{L}$ \\
\hline
\end{tabular}

*sample diluted to $20 \%$.

Thus, the $H$ dulcis fermented alcoholic beverage showed higher antioxidant activity (by DPPH and ABTS methods) and phenolic content than commercial white wine and other beverages described in the literature.

\section{Conclusions}

The fermented alcoholic beverage from $H$. dulcis was elaborated through a simple and reproducible methodology, using a commercial Saccharomyces cerevisiae strain. High total 
phenolic content and antioxidant activity was observed in vitro, for pulp and elaborated fermented, besides metabolites with therapeutic potential, as eugenol, trans-farnesol, salicylates, and dihydromyricetin which reinforces the interest on functional properties of this beverage and opens perspectives for new studies, creating agribusiness opportunities and valorization of this pseudofruit.

\section{Acknowledgements}

The authors thanks CNPq (Conselho Nacional de Desenvolvimento Científico e Tecnológico do Brasil), CAPES (Coordenação de Aperfeiçoamento de Pessoal de Nível Superior) and FAPEMIG (Fundação de Amparo a pesquisa de Minas Gerais) for financial support and scholarships.

\section{References}

Anbu, S., \& Anuradha, C. V. (2012). Protective effect of eugenol against alcohol-induced biochemical changes in rats. International Journal of Research in Biotechnology and Biochemistry, 2(2), 13-18.

Bampi, M., Bicudo, M. O. P., Fontoura, P. S. G., \& Ribani, R. H. (2010). Composição centesimal do fruto, extrato concentrado e da farinha da uva-do-japão. Ciência Rural, 40(11), 2361-2367. http://dx.doi. org/10.1590/S0103-84782010001100018.

Bonvehí, J. S. (2005). Investigation of aromatic compounds in roasted cocoa powder. European Food Research and Technology, 221(1-2), 19-29. http://dx.doi.org/10.1007/s00217-005-1147-y.

Brand-Williams, W., Cuvelier, M. E., \& Berset, C. (1995). Use of free radical method to evaluate antioxidant activity. LebensmittelWissenschaft + Technologie Food Science and Technology, 28(1), 25-30. http://dx.doi.org/10.1016/S0023-6438(95)80008-5.

Breksa, A. P., Takeoka, G. R., Hidalgo, M. B., Vilches, A., Vasse, J., \& Ramming, D. W. (2010). Antioxidant activity and phenolic content of 16 raisin grape (Vitis vinifera L.) cultivars and selections. Food Chemistry, 121(3), 740-745. http://dx.doi.org/10.1016/j. foodchem.2010.01.029.

Carvalho, P. E. R. (1994). Ecologia, silvicultura e usos da uva-do-japão (Hovenia dulcis Thunberg) (Circular Técnica, No. 23, 24 p.). Colombo: EMBRAPA.

Chen, S., Zhao, X., Wan, J., Ran, L., Qin, Y., Wang, X., Gao, Y., Shu, F., Zhang, Y., Liu, P., Zhang, Q., Zhu, J., \& Mi, M. (2015). Dihydromyricetin improves glucose and lipid metabolism and exerts anti-inflammatory effects in nonalcoholic fatty liver disease: a randomized controlled trial. Pharmacological Research, 99, 74-81. PMid:26032587. http:// dx.doi.org/10.1016/j.phrs.2015.05.009.

Childs, B. C., Bohlscheid, J. C., \& Edwards, C. G. (2015). Impact of available nitrogen and sugar concentration in musts on alcoholic fermentation and subsequent wine spoilage by Brettanomyces bruxellensis. Food Microbiology, 46, 604-609. PMid:25475334. http:// dx.doi.org/10.1016/j.fm.2014.10.006.

Dias, D. R., Schwan, R. F., \& Lima, L. C. O. (2003). Metodologia para elaboração de fermentado de cajá (Spondias Mombin L.). Ciência e Tecnologia de Alimentos, 23(3), 342-350. http://dx.doi.org/10.1590/ S0101-20612003000300008.

Duarte, W. F., Dias, D. R., Oliveira, J. M., Teixeira, J. A., Silva, J. B. A., \& Schwan, R. F. (2010). Characterization of different fruit wines made from cacao, cupuassu, gabiroba, jaboticaba and umbu. Food Science and Technology (Campinas), 43, 1564-1572.
Escudero, A., Gogorza, B., Melús, M. A., Ortín, N., Cacho, J., \& Ferreira, V. (2004). Characterization of the aroma of a wine from Maccabeo. Key role played by compounds with low odor activity values. Journal of Agricultural and Food Chemistry, 52(11), 3516-3524. PMid:15161224. http://dx.doi.org/10.1021/jf035341l.

Feng, Y., Liu, M., Ouyang, Y., Zhao, X., Ju, Y., \& Fang, Y. (2015). Comparative study of aromatic compounds in fruit wines from raspberry, strawberry, and mulberry in central Shaanxi area. Food \& Nutrition Research, 59(1), 29290. PMid:26617387. http://dx.doi. org/10.3402/fnr.v59.29290.

Garcia, E. F., Oliveira, M. A., Dourado, L. P. A., Souza, D. G., Teixeira, M. M., \& Braga, F. C. (2016). In vitro TNF- $\alpha$ inhibition elicited by extracts from Echinodorus grandiflorus leaves and correlation w/ ith their phytochemical composition. Planta Medica, 82(4), 337-343.

Gris, E. F., Mattivi, F., Ferreira, E. A., Vrhovsek, U., Pedrosa, R. C., \& Bordignon-Luiz, M. T. (2011). Proanthocyanidin profile and antioxidant capacity of Brazilian Vitisvinifera red wines. Food Chemistry, 126(1), 213-220. http://dx.doi.org/10.1016/j.foodchem.2010.10.102.

Henriques, B. O., Corrêa, O., Azevedo, E. P. C., Pádua, R. M., Oliveira, V. L. S., Oliveira, T. H. C., Boff, D., Dias, A. C. F., Souza, D. G., Amaral, F. A., Teixeira, M. M., Castilho, R. O., \& Braga, F. C. (2016). In Vitro TNF-inhibitory activity of brazilian plants and antiinflammatory effect of Stryphnodendron adstringens in an acute arthritis Model. Evidence-Based Complementary and Alternative Medicine, 2016(2016), 9872598. http://dx.doi.org/10.1155/2016/9872598.

Hou, X., Tong, Q., Wang, W., Xiong, W., Shi, C., \& Fang, J. (2015). Dihydromyricetin protects endothelial cells from hydrogen peroxideinduced oxidative stress damage by regulating mitochondrial pathways. Life Sciences, 130, 38-46. PMid:25818185. http://dx.doi. org/10.1016/j.lfs.2015.03.007.

Hyun, T. K., Eom, S. H., Yu, C. Y., \& Roitsch, T. (2010). Hovenia dulcis - an Asian traditional herb. Planta Medica, 76(10), 943-949. PMid:20379955. http://dx.doi.org/10.1055/s-0030-1249776.

Jung, S.-Y., Lim, J.-S., \& Song, H.-S. (2012). Alcohol dehydrogenase activity and sensory evaluation of hutgae (Hovenia dulcis Thunb) fruit soy sauce. The Korean Journal of Food and Nutrition, 25(4), 747-754. http://dx.doi.org/10.9799/ksfan.2012.25.4.747.

Kuskoski, E. M., Asuero, A. G., Morales, M. T., \& Fett, R. (2006). Frutos tropicais silvestres e polpas de frutas congeladas: atividade antioxidante, polifenóis e antocianinas. Ciência Rural, 36(4), 12831287. http://dx.doi.org/10.1590/S0103-84782006000400037.

Li, G., Min, B. S., Zheng, C., Lee, J., Oh, S. R., Ahn, K. S., \& Lee, H. K. (2005). Neuroprotective and free radical scavenging activities of phenolic compounds from Hovenia dulcis. Archives of Pharmacal Research,28(7), 804-809. PMid:16114495. http://dx.doi.org/10.1007/ BF02977346.

Lins, A. R., \& Sartori, G. V. (2014). Qualidade fenólica e atividade antioxidante de vinhos tintos produzidos no estado do Paraná. Revista Brasileira de Produtos Agroindustriais, 16(1), 69-76. http:// dx.doi.org/10.15871/1517-8595/rbpa.v16n1p69-76.

Miller, N. J., Rice-Evans, C., Davies, M. J., Gopinathan, V., \& Milner, A. (1993). A novel method for measuring antioxidant capacity and its application to monitoring the antioxidant status in premature neonates. Clinical Science, 84(4), 407-412. PMid:8482045. http:// dx.doi.org/10.1042/cs0840407.

Oliveira, M. E. S., Pantoja, L., Duarte, W. F., Collela, C. F., Valarelli, L. T., Schwan, R. F. E., \& Dias, D. R. (2011). Fruit wine produced from cagaita (Eugenia dysenterica DC) by both free and immobilised yeast cell fermentation. Food Research International, 44(7), 2391-2400. http://dx.doi.org/10.1016/j.foodres.2011.02.028. 
Park, E., Ye, E., Kim, S., Choi, H., \& Bae, M. (2006). Eliminatory effect of health drink containing Hovenia dulcis Thunb extract on ethanol-induced hangover in rats. Journal of The Korean Society of Dietary Culture, 21, 71-75.

Park, J. S., Kim, I. S., Rehman, S., Na, C. S., \& Yoo, H. H. (2016). HPLC determination of bioactive flavonoids in Hovenia dulcis fruit extracts. Journal of Chromatographic Science, 54(2), 130-135. PMid:26240190.

Patterson, J. R., \& Lawrence, J. R. (2001). Salicylic acid: a link between aspirin, diet and the prevention of colorectal cancer. The Quarterly Journal of Medicine, 94(8), 445-448. PMid:11493722. http://dx.doi. org/10.1093/qjmed/94.8.445.

Prasad, S. N., Bharath, M. M. S., \& Muralidhara, (2016). Neurorestorative effects of eugenol, a spice bioactive: Evidence in cell model and its efficacy as an intervention molecule to abrogate brain oxidative dysfunctions in the streptozotocin diabetic rat. Neurochemistry International, 95, 24-36. PMid:26519099. http://dx.doi.org/10.1016/j. neuint.2015.10.012.

Qamar, W., \& Sultana, S. (2008). Farnesol ameliorates massive inflammation, oxidative stress and lung injury induced by intratracheal instillation of cigarette smoke extract in rats: an initial step in lung chemoprevention. Chemico-Biological Interactions, 176(2-3), 79-87. PMid:18793622. http://dx.doi.org/10.1016/j.cbi.2008.08.011.

Rao, S. R., \& Ravishankar, G. A. (2000). Vanilla flavour: production by conventional and biotechnological routes. Journal of the Science of Food and Agriculture, 80, 209-304.

Rodriguez-Campos, J., Escalona-Buendía, H. B., Orozco-Avila, I., Lugo-Cervantes, E., \& Jaramillo-Flores, M. E. (2011). Dynamics of volatile and non-volatile compounds in cocoa (Theobroma cacao L.) during fermentation and drying processes using principal components analysis. Food Research International, 44(1), 250-258. http://dx.doi.org/10.1016/j.foodres.2010.10.028.

Rufino, M. S. M., Alves, R. E., Brito, E. S., Pérez-Jiménez, J., SauraCalixto, F., \& Mancini-Filho, J. (2010). Bioactive compounds and antioxidant capacities of 18 non-traditional tropical fruits from Brazil. Food Chemistry, 121(4), 996-1002. http://dx.doi.org/10.1016/j. foodchem.2010.01.037.

Santhanasabapathy, R., \& Sudhandiran, G. (2015). Farnesol attenuates lipopolysaccharide-induced neurodegeneration in Swiss albino mice by regulating intrinsic apoptotic cascade. Brain Research, 1620, 42-56. PMid:25935694. http://dx.doi.org/10.1016/j.brainres.2015.04.043.

Schwan, R. F., Mendonça, A. T., \& Silva, J. J. Jr. (2001). Microbiology and physiology of cachaça (aguardente) fermentations. Antonie van Leeuwenhoek, 79(1), 89-96. PMid:11392489. http://dx.doi. org/10.1023/A:1010225117654.

Shen, Y., Lindemeyer, A. K., Gonzalez, C., Shao, X. M., Spigelman, I., Olsen, R. W., \& Liang, J. (2012). Dihydromyricetin as a novel anti-alcohol intoxication medication. The Journal of Neuroscience, 32(1), 390-401. PMid:22219299. http://dx.doi.org/10.1523/ JNEUROSCI.4639-11.2012.
Souza, F. K. F., Luz, R. O., Santos, C. M. E., Pietrowski, G. A. M., Wosiacki, G., \& Nogueira, A. (2011). Desenvolvimento de fermentadores em série para o estudo cinético de fermentado de maçã. Revista Brasileira de Tecnologia Agroindustrial, 5(1), 379-386.

Stratil, P., Kubáň, V., \& Fojtová, J. (2008). Comparison of the phenolic content and total antioxidant activity in wines as determined by spectrophotometric methods. Czech Journal of Food Sciences, 26, 242-253.

Torres, A. B.No., Silva, M. E., Silva, W. B., Swarnakar, R., \& Silva, F. L. H. (2006). Cinética e caracterização físico-química do fermentado do pseudofruto do caju (Anacardium occidentale L.). Quimica Nova, 29(3), 489-492. http://dx.doi.org/10.1590/S0100-40422006000300015.

Tsimogiannis, D., Samiotaki, M., Panayotou, G., \& Oreopoulou, V. (2007). Characterization of flavonoid subgroups and hydroxy substitution by HPLC-MS/MS. Molecules, 12(3), 593-606. PMid:17851414. http:// dx.doi.org/10.3390/12030593.

Vararu, F., Moreno-García, J., Zamfir, C., Cotea, V. V., \& Moreno, J. (2016). Selection of aroma compounds for the differentiation of wines obtained by fermenting musts with starter cultures of commercial yeast strains. Food Chemistry, 197(Pt A), 373-381. PMid:26616963. http://dx.doi.org/10.1016/j.foodchem.2015.10.111.

Vinholes, J., Rudnitskaya, A., Gonçalves, P., Martel, F., Coimbra, M. A., \& Rocha, S. M. (2014). Hepatoprotection of sesquiterpenoids: a quantitative structure-activity relationship (QSAR) approach. Food Chemistry, 146, 78-84. PMid:24176316. http://dx.doi.org/10.1016/j. foodchem.2013.09.039.

Waterhouse, A. L. (2005). Determination of total phenolics. In R. E. Wrolstad (Ed.), Handbook of food analytical chemistry: pigments, colorants, flavors, texture and bioactive food components (pp. 463464). New York: John Wiley and Sons.

Xiang, J., Zhu, W., Han, J., Li, Z., Ge, H., \& Lin, D. (2012). Analysis of organic acids in Chinese Raisin Tree (Hovenia dulcis) peduncle and their changes in liquid fermentation process. Food Science and Biotechnology, 21(4), 1119-1127. http://dx.doi.org/10.1007/ s10068-012-0146-6.

Xiao, Z., Fang, L., Niu, Y., \& Yu, H. (2015). Effect of cultivar and variety on phenolic compounds and antioxidant activity of cherry wine. Food Chemistry, 186, 69-73. PMid:25976793. http://dx.doi.org/10.1016/j. foodchem.2015.01.050.

Yoo, S. M., Mun, S., \& Kim, J. H. (2006). Recovery and pre-purification of (+)-dihydromyricetin from Hovenia dulcis. Process Biochemistry, 41(3), 567-570. http://dx.doi.org/10.1016/j.procbio.2005.10.008.

Yoshikawa, K., Nagai, M., Wakabayashi, M., \& Arihara, S. (1993). Aroma glycosides from Hovenia dulsis. Phytochemistry, 34(5), 1431-1433. PMid:7764288. http://dx.doi.org/10.1016/0031-9422(91)80044-2.

Zhang, Q., Liu, J., Liu, B., Xia, J., Chen, N., Chen, X., Cao, Y., Zhang, C., Lu, C., Li, M., \& Zhu, R. (2014). Dihydromyricetin promotes hepatocellular carcinoma regression via a p53 activation-dependent mechanism. Scientific Reports, 4(1), 4628. PMid:24717393. http:// dx.doi.org/10.1038/srep04628. 